\title{
Acute Events in Hospitalized Patients with Sickle Cell Anemia before and after the Use of Hydroxyurea
}

Olinda Maria Rodrigues de Araújo1, Maria Lúcia Ivo, Albert Schiaveto de Souza1, Ana Tereza Gomes Guerrero², Alexandra Maria Almeida Carvalho', Francine Ramos de Miranda ${ }^{1}$, Maria Angélica Marcheti ${ }^{1}$, Abílio Torres dos Santos Neto ${ }^{1}$, Elaine Silva de Pádua Melo, Isabelle Campos de Azevedo3, Magda Maria Barbosa da Silva, Ricardina Oliveira da Silva ${ }^{3}$, Marcos Antonio Ferreira Júnior ${ }^{3}$

\section{Abstract}

Objective: To estimate the occurrence of acute events in hospitalized patients with sickle cell anemia (SCA) before and after the use of hydroxyurea (HU).

Method: The study has a quantitative approach, of analytical cohort type developed in two public referral hospitals in the Midwest region of Brazil, from November 2010 to October 2011. Data collection was performed on records of patients diagnosed with SCA. The interval time for the data collection was 30 years, which corresponded between 1980 and 2010. The research was approved by the Ethics Committee of the Federal University of Mato Grosso do Sul, Campo Grande/MS, Brazil, under protocol 1822/2010.

Results: The sample had 32 medical records of hospitalized patients diagnosed with SCA who used HU. The mean age of the participants was $25.65 \pm 11.92$; the average time of drug exposure was $6.0 \pm 2.8$ years; the average initial dose was $17.00 \pm 5.3 \mathrm{mg} / \mathrm{kg} /$ day and final dose of $22.10 \pm 5.3 \mathrm{mg} / \mathrm{kg} / \mathrm{day}$. After using $\mathrm{HU}$, the fetal hemoglobin ranged from $8.41 \pm 0.95$ to $14.44 \pm 13.7 \%(p<0.001)$. There was a reduction of the average leucocyte, absolute neutrophil, acute events, total infections and blood transfusions.

Conclusion: The effects of $\mathrm{HU}$ exposure caused an increase in fetal hemoglobin level, decreasing leukocyte, absolute neutrophils and acute events, transfusions and hospitalizations by the use of non-opioid.
1 Federal University of Mato Grosso do Sul/UFMS, Campo Grande/MS, Brazil.

2 Osvaldo Cruz Foundation/FIOCRUZ, Campo Grande/MS, Brazil.

3 Federal University of Rio Grande do Norte/UFRN, Natal/RN, Brazil.

Contact information:

Marcos Antonio Ferreira Júnior.

Address: Universidade Federal do Rio Grande do Norte, Centro de Ciências da Saúde, Departamento de Enfermagem. Avenida Salgado Filho, S/N, Lagoa Nova, Natal/RN, Brasil. CEP: 59078-970.

” marcos_nurse@hotmail.com

Keywords

Sickle Cell Anemia;

Hydroxyurea; Infection. 


\section{Introduction}

Sickle cell anemia (SCA) is a genetic disorder caused by the homozygous of gene $\beta^{s}$ encoding the hemoglobin $\mathrm{S}(\mathrm{HbS})$. The $\mathrm{HbS}$ results from the substitution of glutamic acid (GAG) by valine (GTG) at position six of the globin $\beta$ chain. This exchange results in profound changes in the physicochemical properties of the molecule of hemoglobin $(\mathrm{Hb})$ when deoxygenated $[1,2]$. Such changes occur in cell morphology, and the RBCs are an elongate form known as "sickle erythrocyte" altering the rheology of red blood cells and the erythrocyte membrane and results in the polymerization phenomenon $[3,4]$. These changes culminate in two important pathophysiological processes of sickle cell anemia, hemolysis, and vase-occlusion [5].

The occurrence of the vase-occlusive episode is the pathophysiological event decisive for the origin of most of the signs and symptoms of the clinical picture of patients with SCA and other manifestations or acute events that are worth mentioning, as the painful crises, aplastic, hemolytic, pulmonary complications, neurological and hepatobiliary as well as infections [6, 7]. From these events, the pain crisis is considered the most dramatic event in the picture of the disease [8].

The polymerization phenomenon is regulated by the level of $\mathrm{HbS}$ and decreasing with the presence of other forms of hemoglobin that does not contain mutant forms of the $\beta$ globin. The main therapeutic approach to SCA is trying to change the production of hemoglobin $S$ for fetal hemoglobin $(\mathrm{HbF})$, resulting in a less severe degree of symptoms and less hemolytic anemia [9]. For cases with an indication, the treatment with hydroxyurea $(\mathrm{HU})$ may be instituted to ameliorate the clinical picture of the disease [10].

By its action, the $\mathrm{HU}$ elevates $\mathrm{HbF}$ and consequently decreases the vase-occlusion and hemolysis, resulting in the reduction of the frequency of transfusions, painful events, number, and duration of hospitalization. This treatment further enhances the hematological parameters and increases nitric oxide concentrations, depending on the inhibitory role of HbS polymerization [11]. The effective therapeutic action is observed in observational studies [12] and demonstrated in Randomized Clinical Trial (RCT) with serious adults [13].

The benefits of using HU found that early drug exposure to the patient brings a greater likelihood of mortality prevention [14]. Given the above, this study aimed to estimate the occurrence of acute events in hospitalized patients with sickle cell anemia before and after the use of hydroxyurea as a treatment option.

\section{Method}

This is a study with a quantitative approach, of the analytical cohort type developed in two public referral hospitals in the Midwest Brazil, from November 2010 to October 2011.

Data collection was performed on records of patients diagnosed with sickle cell anemia (HbSS). The interval time for the data collection was 30 years, which corresponded between 1980 and 2010. Patients with at least 24 hours of hospitalization, with a diagnosis of sickle cell anemia confirmed by hemoglobin electrophoresis and having a medical indication for $\mathrm{HU}$ treatment were included.

The hematological variables collected were: fetal hemoglobin ( $\mathrm{HbF}$ ); total hemoglobin concentration; hematocrit; erythrocytes or RBCs; leukocytes, absolute neutrophils, and platelets, collected before and after the HU use. The evaluation of laboratory parameters in this study followed the values espoused by Failace [15] Falcão and Calado [16]. The absolute number of neutrophils is the total of neutrophils about leukocytes [15], calculated using the formula: absolute neutrophil $=$ neutrophils $\mathrm{x}$ leukocytes/100.

The clinical variables collected were: hydroxyurea (starting date, age at the beginning of the treatment, initial dose, final dose and average ex- 
posure time) and acute events before and after the use of HU (pain crises, acute chest syndrome/ pneumonias - STA/pneumonias), infections, sepsis, priapism, stroke, cholelithiasis, aplastic crisis and the number of blood transfusions). Other variables were related to hospitalizations using opioid analgesics, non-opioid analgesics.

The acute events were defined according to criteria established by the Ministry of Health of Brazil. [17] In the variable of acute events, all events were included, including pain crisis. It was opted for this study to analyze the frequency of painful crisis as an independent variable separately. Moreover, in the variable infections, all infections are included in general, including pneumonia. It was also decided to examine separately pneumonia to be more frequent infections in sickle cell disease.

For the relationship of individualized $\mathrm{mg} / \mathrm{kg}$ to the $\mathrm{HU}$ dosage, the data on the weight of each patient and the prescribed dose recorded in the medical record were used, both before and after use.

When analyzing the results, the comparison between the moments before and after the use of HU was performed using the Wilcoxon test when the samples did not pass the normality test, or through the $\mathrm{t}$ Student test when they passed the normality test. The other results of the variables evaluated in this study were presented in descriptive statistics. The statistical program used was SigmaStat, version 3.5 and the level of significance was $p<0.05$.

The study was previously evaluated and approved in its ethical, and methodological aspects by the Ethics Committee in Research of the Federal University of Mato Grosso do Sul, Campo Grande/MS, Brazil, under protocol 1822/2010.

\section{Results}

The sample was 32 medical records of hospitalized patients diagnosed with SCA who used HU. The mean age of subjects was $25.65 \pm 11.92$, which in- dicates that most of the patients were in the third decade of life. The average time of exposure to drug was $6.0 \pm 2.8$ years, and the mean initial dose was $17.00 \pm 5.3 \mathrm{mg} / \mathrm{kg} /$ day, and the final dose was $22,10 \pm 5.3 \mathrm{mg} / \mathrm{kg} / \mathrm{day}$.

Figure 1 shows the percentage of $\mathrm{HbF}$ level reached in this sample after using HU. This result demonstrates the effectiveness of the drug, which resulted in a significant increase in $\mathrm{HbF}(\mathrm{p}$ $<0.001)$.

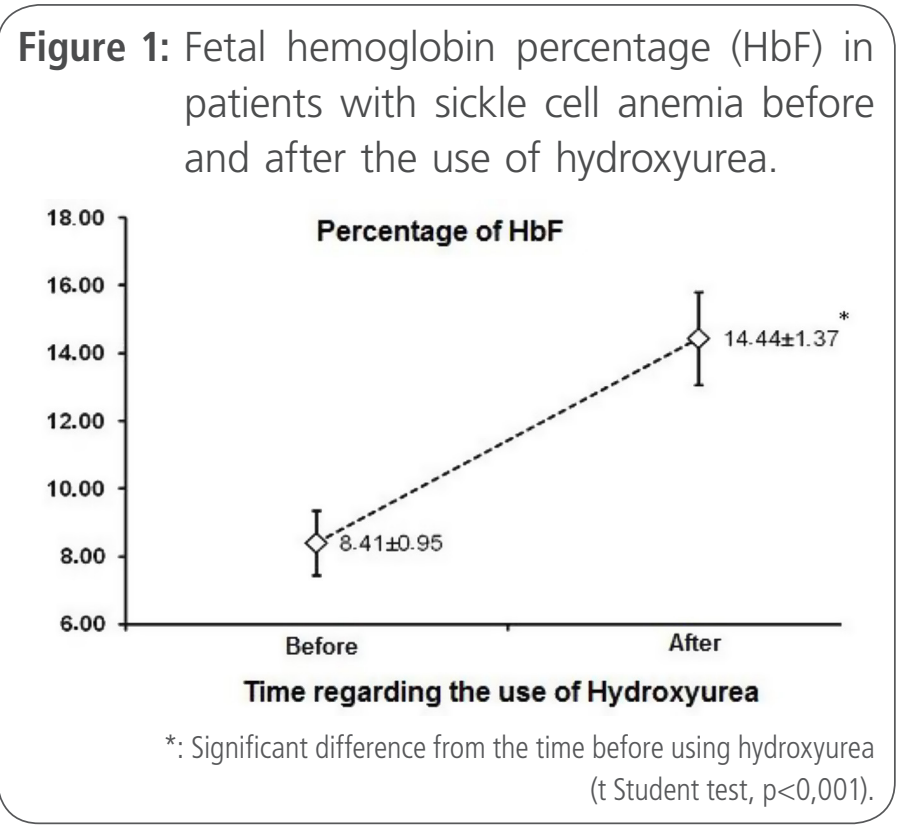

The leukocytes showed a significant reduction in the use of hydroxyurea (Table 1).

Table 1. Hematological parameters in patients with sickle cell anemia before and after the use of hydroxyurea between 1980 and 2010 . Campo Grande/MS, Brazil, 2016 ( $n=32)$.

\begin{tabular}{l|c|c|c|}
\hline \multirow{2}{*}{ Variable } & \multicolumn{2}{|c|}{ Time regarding the use of hydroxyurea } & P-value \\
\cline { 2 - 3 } & Before $^{1}$ & After $^{1}$ & \\
\hline $\begin{array}{l}\text { Hemoglobin } \\
\text { (g/dL) }\end{array}$ & $8.08 \pm 0.22$ & $8.04 \pm 0.22$ & 0.973 \\
\hline $\begin{array}{l}\text { Hematocrit } \\
(\%)\end{array}$ & $25.30 \pm 0.64$ & $24.55 \pm 0.66$ & 0.465 \\
\hline $\begin{array}{l}\text { Erythrocytes } \\
\left(10^{6} / \mu \mathrm{L}\right)\end{array}$ & $2.7 \pm 78544.01$ & $2.5 \pm 77034.80$ & 0.119 \\
\hline $\begin{array}{l}\text { Leukocyte } \\
\left(10^{3} / \mu \mathrm{L}\right)\end{array}$ & $15.986 \pm 1044.72$ & $13.984 \pm 947.32$ & $0.0422^{2}$ \\
\hline
\end{tabular}




\begin{tabular}{|c|c|c|c|}
\hline \multirow{2}{*}{ Variable } & \multicolumn{2}{|c|}{ Time regarding the use of hydroxyurea } & \multirow{2}{*}{ P-value } \\
\hline & Before $^{1}$ & After $^{1}$ & \\
\hline $\begin{array}{l}\text { Absolute } \\
\text { neutrophil } \\
(\mathrm{mL})\end{array}$ & $11157.32 \pm 908.64$ & $10070.20 \pm 742.32$ & 0.185 \\
\hline $\begin{array}{l}\text { Platelets } \\
\left(10^{3} \mu \mathrm{L}\right)\end{array}$ & $277.964 .29 \pm 21087.34$ & $320.160 .00 \pm 20842.72$ & 0.278 \\
\hline \multicolumn{4}{|c|}{$\begin{array}{r}\text { 1: Data are presented as mean } \pm \text { standard error of the mean. } \\
\text { 2: p-value with a significant difference between the times before and } \\
\text { after use of hydroxyurea. }\end{array}$} \\
\hline
\end{tabular}

In Table 2, there are the results for the mean and standard deviation of clinical variables, normalized to a period of 10 years in hospitalized patients with sickle cell anemia before and after the use of $\mathrm{HU}$. After the drug use, there was a significant reduction in hospitalizations for treatment with non-opioid analgesics in acute events infections, pneumonia and blood transfusions.

Table 2. Average number of hospitalizations and acute events (normalized to a period of 10 years) seen in patients with sickle cell anemia before and after the use of hydroxyurea between 1980 and 2010. Campo Grande/MS, Brasil, 2016 ( $n=32$ ).

\begin{tabular}{|l|c|c|c|}
\hline \multicolumn{1}{|c|}{$\begin{array}{l}\text { Variable } \\
\text { (Average every 10 years) }\end{array}$} & $\begin{array}{c}\text { Time regarding the use of } \\
\text { hydroxyurea }\end{array}$ & P-value \\
\cline { 2 - 4 } & \multicolumn{1}{|c|}{ Before $^{1}$} & \multicolumn{1}{|c|}{ After $^{1}$} & \\
\hline $\begin{array}{l}\text { Interactions with non- } \\
\text { opioid analgesics }\end{array}$ & $10.65 \pm 1.76$ & $6.51 \pm 1.29$ & $0.014^{2}$ \\
\hline $\begin{array}{l}\text { Interactions with opioid } \\
\text { analgesics }\end{array}$ & $7.34 \pm 1.27$ & $5.27 \pm 1.03$ & 0.127 \\
\hline $\begin{array}{l}\text { Acute events } \\
\text { Pain crises }\end{array}$ & $14.16 \pm 2.62$ & $7.05 \pm 1.48$ & $0.014^{2}$ \\
\hline Infections & $8.20 \pm 1.47$ & $5.32 \pm 1.17$ & 0.264 \\
\hline Pneumonias & $1.58 \pm 0.52$ & $0.35 \pm 0.17$ & $0.005^{2}$ \\
\hline Blood transfusions & $2.80 \pm 0.79$ & $0.79 \pm 0.36$ & $0.012^{2}$ \\
\hline & $20.12 \pm 4.56$ & $10.43 \pm 2.10$ & $0.037^{2}$ \\
\hline
\end{tabular}

1: Data are presented as mean \pm standard error of the mean. 2: p-values significant difference between before and after the use of hydroxyurea (Wilcoxon Test).

\section{Discussion}

After using $\mathrm{HU}$, there was a significant increase in $\mathrm{HbF}$ level of $8.41 \pm 0.95$ to $14.44 \pm 1.37 \%$, with an initial medication dosage of $17 \mathrm{mg} / \mathrm{kg} /$ day and final dose of $22.10 \mathrm{mg} / \mathrm{kg} /$ day. The results of this study demonstrated the effectiveness of medicine treatment for SCA. These findings are like those found in an observational study that evaluated the pharmacokinetics, toxicity and HbF production with a sample of $32 \mathrm{HbSS}$ patients. In this study, the mean age ranged from $27.60 \pm 6.3$ years, but the initial dosage was $10 \mathrm{mg} / \mathrm{kg} /$ day and ranged up to $35 \mathrm{mg} / \mathrm{kg} /$ day, as there was a significant increase in $\mathrm{HbF}$ of $4 \pm 2$ to $15 \pm 6 \%$ after its use, $\mathrm{p}<0.001$ [12].

In adults, g globin genes have a normal sequence, but remain almost inactive at this stage. However, in exceptional conditions, these genes are activated to produce red blood cells with highly enriched $\mathrm{Hb}$, composed of $\alpha$ and $\mathrm{g}$ chains called as $\mathrm{HbF}$. The $\mathrm{HU}$ acts while acting in g globin genes from primitive progenitors and it forces the production of $F$. This process causes cells to change the kinetics of erythroid proliferation, and produces nitric oxide that acts directly in the production of $\mathrm{HbF}$. [9]

The use of $\mathrm{HU}$ in patients with sickle cell anemia is the result of research carried out at the end of the 1970s, in which it was demonstrated that the change in vivo of the erythropoiesis kinetic arises from the HU when inducing the production of fetal hemoglobin [18].

Interestingly, erythrocytes, hemoglobin, and hematocrit with averages already reduced before the use of HU did not increase after treatment with the drug. These results differ from those observed in another study which varied dosage of $10 \mathrm{mg} / \mathrm{kg} /$ day to $35 \mathrm{mg} / \mathrm{kg} /$ day performed in people with sickle cell disease [12].

In this study, the leukocytosis showed a significant reduction in the use of $\mathrm{HU}$. These findings corroborate the research that highlighted the key role of leukocytes in the oxidative and inflammatory stress process. Accordingly, leukocytosis may occur due to increased levels of cytokines my- 
eloid proliferative and delayed apoptotic process [19]. Furthermore, leukocytes play a central role in initiating vase-occlusive event since from these cells there is the aggregation of other blood cells (erythrocytes, platelets) that promote the narrowing of the vessel lumen. This phenomenon affects the circulation and leads to hypoxia. In response, leukocytes will produce cytokines that induce the expression of adhesion molecules by vascular endothelium [20].

The absolute neutrophils showed a small reduction in their average values. In a study of patients diagnosed with SCA residents in the United States and Canada it was found that after two years of therapy with $\mathrm{HU}$, there were half of the patients with an increase in $\mathrm{HbF}$ with reduced leukocytes and consequent improvement of the disease in the experimental group [13].

In this study, the acute events showed a significant reduction in the average after the use of $\mathrm{HU}$. The effect of this drug reduces the incidence of vase-occlusive crisis supposedly by elevated HbF, with improvement in patients' symptoms [21]. Evidence of the effect of $\mathrm{HU}$ is demonstrated with the explosion of young $\mathrm{F}$ cells within 72 hours [22].

The reduction of acute events after the use of $\mathrm{HU}$ emphasizes the complexity of the vase-occlusive process in sickle cell anemia, not completely understood condition and participation of neutrophil as the vase-occlusive event initiators. In this sense, polymorphonuclear neutrophils (PMN) are activated by direct interaction sickled erythrocytes (SS-RBC), which takes the PMN to play a crucial role in the cascade of events leading up to the crisis. Therapeutic interventions intended to reduce SS-RBC-PMN [21].

As for the total of acute events in this study, there was a reduction in the use of HU. In a Brazilian study, there was a reduction of three events: painful crises (1.86 to $0.81, p=0.0014$ ), acute chest syndrome (from 0.35 to $0.08, p=0.0045$, infections (1.03 to $0.5, p=0.047$ ) [23].
In this study, pain crises did not show a significant reduction, but its frequency decreased after using HU. In addition to this event, there was a significant reduction in the mean of transfusions and hospitalizations. These results corroborate an RCT developed with 299 patients, in which there was a reduction in crisis rate in treated patients (mean 2.5 vs. 4.5 crises/year, $p<0.001)$ compared to placebo, as well as in transfusions and hospitalizations [13]. A systematic review study aimed at identifying in the literature and gathering the scientific evidence showing effectiveness, barriers, and toxicity of the use of HU in children with SCA, also found reduced pain episodes and hospitalizations [24]. Another review gathered scientific evidence on the management of sickle cell disease, and it strongly recommends the use of hydroxyurea for adults with 3 or more vase-occlusive crises per year, with episodes of pain that interfere with their daily lives. [25]

Regarding the hospitalizations for treatment of acute events with opioid analgesics and non-opioid after using $\mathrm{HU}$, there was an average reduction in the frequency requirements of these analgesics and significant reduction of the use of non-opioids. In the therapeutic approach, morphine is the opioid agonist most widely used for pain control, and meperidine is contraindicated for patients with sickle cell disease, because there may be physical dependence [8].

In infections, there was a significant reduction of the mean values in this study after using HU. In a survey of 43 children with sickle cell anemia (93\% asplenia or almost asplenia), the spleen filtering function was measured before and during therapy with maximally tolerated dose of $\mathrm{HU}$ and average use of 2.6 years. Of this total, six patients (14\%) had the spleen function completely recovered [26]. The spleen in the initial state of hipoesplenia presented reversibility function in response to certain treatments such as hydroxyurea [27].

The most frequent acute event among the infections in the sample studied was pneumonia. To 
discuss this finding, it was based on a retrospective study that showed an incidence of $16 \%$ of serious bacterial infections, mostly pneumonia being without records in the use of $\mathrm{HU}[28,29]$.

Limitations of this study are related to some variables that were not systematically in the records and prevented them from making some interesting analysis. It is emphasized that these limitations did not prevent achieving the goal of current research.

\section{Conclusion}

The results of this study showed that after the use of hydroxyurea in patients with sickle cell anemia (SCA), there was a significant increase in the level of $\mathrm{HbF}$, significant reduction in mean leukocyte values, absolute neutrophils, as well as in acute events, transfusions and hospitalizations for use non-opioid in the sample investigated. It is suggested to carry out further studies with an experimental approach to find what is the ideal dose of HU to be administered to patients with sickle cell anemia.

\section{References}

1. McGann PT, Ware RE. Hydroxyurea for sickle cell anemia: what have we learned and what questions still remain? Curr Opin Hematol. 2011; 18(3):158-65. Available from: http://www.ncbi. nlm.nih.gov/pubmed/21372708

2. Pelizaro $B I$, Ivo ML, Domingos CRB, Araújo OMR, Salazar EAVM, Ferreira Júnior MA. Hydroxyurea in the sickle cell anemia: toxicity and effectiveness. Rev enferm UFPE on line. 2012; 6(8):1864-70. Available from: http://www.revista.ufpe.br/revistaenfermagem/ index.php/revista/article/viewArticle/2667

3. Zago MA, Pinto ACS. The pathophysiology of sickle cell disease: from the genetic mutation to multiorgan disfunction. Rev Bras Hematol Hemoter. 2007; 29(3):207-14. Available from: http:// www.scielo.br/pdf/rbhh/v29n3/v29n3a03.pdf

4. Fitzhugh $C D$, Hsieh $M M$, Allen $D$, Coles WA, Seamon $C$, Ring M, Zhao X, Minniti CP, Rodgers GP, Schechter AN, Tisdale JF, Taylor VI JG. Hydroxyurea-Increased Fetal Hemoglobin Is Associated with Less Organ Damage and Longer Survival in Adults with Sickle Cell Anemia. PLOS ONE. 2015;
5. Booth C, Inusa B, Okaro SK. Infection in sickle cell disease: A review. Int J Infect Dis. 2010; 14: e2- e12. Available from: http:// www.ncbi.nlm.nih.gov/pubmed/19497774

6. Costa FF. Anemia falciforme. In: Zago MA, Falcão RP, Pasquini R. Hematologia: Fundamentos e prática. São Paulo: Atheneu, 2004, cap.30, 289-307.8v. Platt OS. Hydroxyurea for the treatment of sickle cell anemia. N Engl J Med, 2008; 358, 1362-9. Available from: http://www.uniklinik-duesseldorf. de/fileadmin/Datenpool/einrichtungen/klinik fuer kinder onkologie haematologie und immunologie id26/dateien/ Hydroxyurea reviewPlatt NEJM.pdf

7. Ivo ML. Carvalho EC. Nursing care to patiens with sickle cell disease in the light of Roy's model. Rev Latino-Am. Enfermagem. 2003; 11(2):192-8. Available from: http://www.scielo.br/pdf/ rlae/v11n2/v11n2a08.pdf

8. Lobo C, Marra VN, Silva RMG. Painful episodes in sickle cell disease. Rev Bras Hematol Hemoter. 2007; 29(3):247-58. Available from: http://www.scielo.br/pdf/rbhh/v29n3/v29n3a11.pdf

9. Platt OS. Hydroxyurea for the treatment of sickle cell anemia. N Engl J Med, 2008; 358, 1362-9. Available from: http://www. uniklinik-duesseldorf.de/fileadmin/Datenpool/einrichtungen/ klinik fuer kinder onkologie haematologie und immunologie_id26/dateien/Hydroxyurea_reviewPlatt_NEJM.pdf

10. Silva MC, Shimauti ELT. Effectiveness and toxicity of hydroxyurea in children with sickle cell anemia. Rev Bras Hematol Hemoter. 2006; 28(2):144-48. Available from: http://www.scielo.br/pdf/ rbhh/v28n2/v28n2a16.pdf

11. Davies SC, Gilmore, A. The role of hydroxyurea in management of sickle cell disease. Blood Rev. 2003; 17(2):99-109. Available from: http://www.ncbi.nlm.nih.gov/pubmed/12642122

12. Charache S, Dover GJ, Moore RD, Eckert S, Ballas SK, Koshy $M$, et al. Hydroxyurea: effects on hemoglobin $F$ production in patients with sickle cell anemia. Blood. 1992; 79(10):2555-65. Available from: http://www.ncbi.nlm.nih.gov/pubmed/1375104 13. Charache S, Terrin ML, Moore RD, Dover GJ, Barton FB, Eckert SV, et al. Multicenter study of hydroxyurea in sickle cell anemia: effect of hydroxyurea on the frequency of painful crises in sickle cell anemia. N Engl J Med. 1995; 332:131722. Available from: http://www.nejm.org/doi/full/10.1056/ NEJM199505183322001\#t=article

14. Steinberg MH, Carthy WF, Castro O, Ballas SK, Armstrong FD, Smith $W$, et al. The risks and benefits of long-term use of hydroxyurea in sickle cell anemia: A 17.5 year follow-up. Am J Hematol. 2010; 85(6):403-8. Available from: http://www.ncbi. nlm.nih.gov/pubmed/20513116 
15. Failace R. Hemograma. Manual de interpretação. In: Failace R. Leucograma. Porto Alegre: Artmed, 2009, cap.13, 239-47.

16. Falcão RP, Calado RT. Heterogeneidade das células do sangue. Órgãos hematopoéticos e linfopoéticos. In: Zago MA, Falcão RP, Pasquini R. Hematologia: Fundamentos e prática. São Paulo: Atheneu, 2004, cap.1, 3-13.

17. Brasil. Ministério da Saúde. Portaria $n^{\circ} 55$, de 29 de janeiro de 2010. Aprova em forma de anexo da Portaria, o Protocolo Clínico e Diretrizes Terapêuticas- Doença Falciforme. Diário Oficial da União, Brasília, DF, N. 21 - Seção 1, 1 fev. de 2010.

18. Stamatoyannopoulos G. Control of globin gene expression during development and erythroid differentiation. Exp Hematol. 2005; 33(3):259-71. Available from: http://www.ncbi.nlm.nih. gov/pubmed/15730849

19. Conran N, Saad ST, Costa FF, Ikuta T. Leukocyte numbers correlate with plasma levels of granulocyte-macrophage colony-stimulating factor in sickle cell disease. Ann Hematol. 2007; 86(4):255-61. Available from: http://www.ncbi.nlm.nih. gov/pubmed/17205286

20. Madigan C, Malik P. Pathophysiology and therapy for haemoglobinopathies. Part I: sickle cell disease. Exp Rev Mol Biol 2006; 8:1-23. Available from: http://www.ncbi.nlm.nih.gov/ pubmed/16690007

21. Hofstra TC, Kalra VK, Meiselman HJ, Coates TD. Sickle erythrocytes adhere to polymorphonuclear neutrophils and activate the neutrophil respiratory burst. Blood 1996; 87(10):4440-7. Availble from: http://www.ncbi.nlm.nih.gov/ pubmed/8639806

22. Platt OS, Orkin SH, Dover G, Beardsley GP, Miller B, Nathan DG. Hydroxyurea enhances fetal hemoglobin production in sickle cell anemia. J Clin Invest. 1984; 74(2):652-56. Available frm: http://www.ncbi.nlm.nih.gov/pmc/articles/PMC370519/

23. Silva-Pinto AC, Angulo IL, Brunetta DM, Neves Fl, Bassi SC, Santis GC, Covas DT. Clinical and hematological effects of hydroxyurea therapy in sickle cell patients: a single-center experience in Brazil. Sao Paulo Med J. 2013;131(4):238-43.

24. Strouse JJ, Heeney MM. Hydroxyurea for the treatment of sickle cell disease: efficacy, barriers, toxicity, and management in children. Pediatr Blood Cancer. 2012; 59(2):365-71. Available from: http://www.ncbi.nlm.nih.gov/pubmed/22517797
25. Yawn BP, Buchanan GR, Afenyi-Annan AN, et al. Management of Sickle Cell Disease: Summary of the 2014 Evidence-Based Report by Expert Panel Members. JAMA. 2014;312(10):10331048. doi:10.1001/jama.2014.10517.

26. William BM, Corazza GR. Hiposplenism: a comprehensive review. Part I: Basic concepts and causes. Haematology 2007; 12:1-13. Available from: http://www.ncbi.nlm.nih.gov/ pubmed/17364987

27. Hankins JS, Helton KJ, McCaryille MB, CS Li, Wang WC, Ware RE. Preservation of spleen and brain function in children with sickle cell anemia treated with hydroxyurea. Pediatr Blood Cancer. 2008; 50(2):293-97. Availble from: http://www.ncbi. nlm.nih.gov/pubmed/17554794

28. Bansil NH, Kim TY, Tieu L, Barcega B. Incidence of serious bacterial infections in febrile children with sickle cell disease. Clin Pediatr (Phila). 2013; 52(7):661-66. Available from: http://www.ncbi.nlm.nih.gov/pubmed/23661790.

29. Araujo OMR, Ivo ML, Ferreira Júnior MA, Pontes ERJC, Bispo IMGP, Oliveira ECL. Survival and mortality among users and non-users of hydroxyurea with sickle cell disease. Rev. Latino-Am. Enfermagem. 2015;23(1):67-73. Available from: http://www.scielo.br/scielo.php?script=sci arttext\&pid=S01041 $1692015000100067 \& \operatorname{lng}=$ en

\section{Publish in International Archives of Medicine}

International Archives of Medicine is an open access journal publishing articles encompassing all aspects of medical science and clinical practice. IAM is considered a megajournal with independent sections on all areas of medicine. IAM is a really international journal with authors and board members from all around the world. The journal is widely indexed and classified Q2 in category Medicine. 